\title{
HADITS-HADITS RAJAM DALAM SHAHIHAIN
}

\author{
Muhammad Asgar Muzakki ${ }^{1}$ \\ asgarmuzakki@gmail.com
}

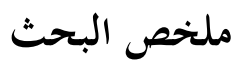

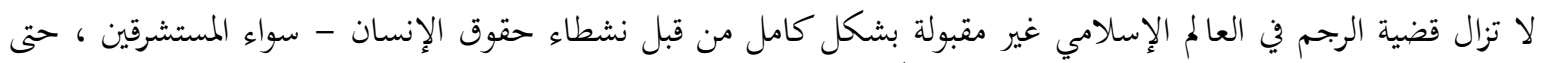

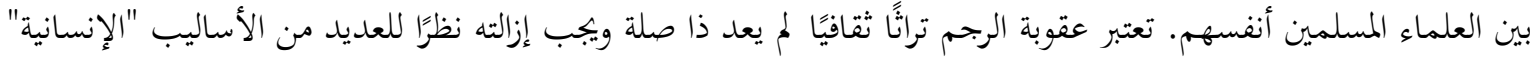

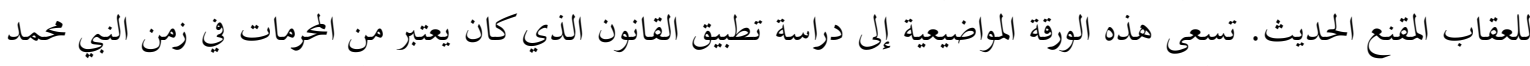

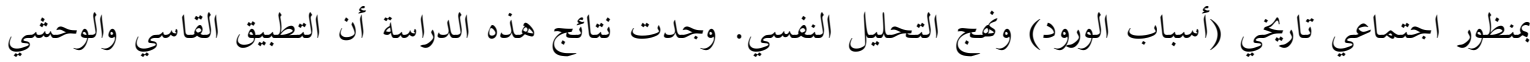

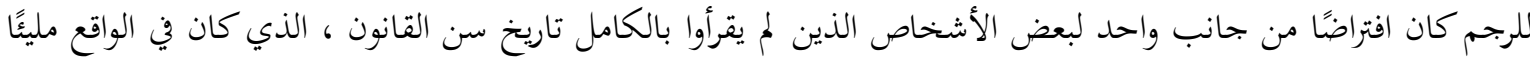

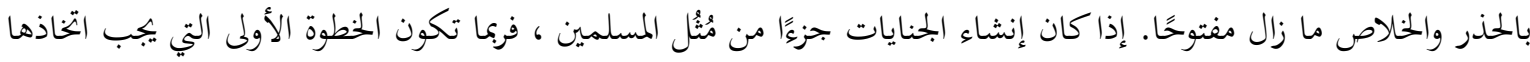

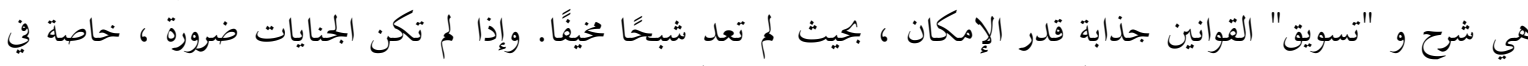

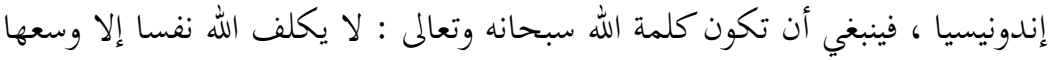

\section{Abstrak}

Persoalan hukum rajam dalam dunia Islam masih belum sepenuhnya diterima oleh para pegiat HAM - baik orientalis, bahkan di kalangan cendekiawan muslim sendiri. Hukuman rajam dianggap sebagai warisan budaya prmiordialis yang sudah tidak relevan lagi dan harus ditiadakan karena banyaknya metode hukuman persuasif modern yang lebih 'manusiawi'. Tulisan ini berusaha mengkaji penerapan hukum yang dianggap tabu tersebut pada masa Rasulullah SAW dengan pendekatan hadis perspektif sosio-historis (asbab al-wurud) dan psiko-analisis. Hasil penelitian ini menemukan bahwa kejam dan brutalnya penerapan had rajam adalah asumsi sepihak sebagian orang yang tidak secara utuh membaca sejarah diberlakukannya hukum tersebut, yang pada kenyataannya penuh

kehati-hatian dan masih terbuka jalan keselamatan bagi pelaku (salvation). Apabila tegaknya jinayat adalah bagian dari cita-cita kaum muslimin, barangkali langkah pertama

yang harus ditempuh adalah menjelaskan dan 'memasarkan' hukum-hukum tersebut semenarik mungkin, hingga ia tak lagi jadi sebuah momok yang menakutkan. Dan jika

jinayat tidak kunjung menjadi sebuah keniscayaan, khususnya di Indonesia, maka seyogyanya berpegang dengan firman Allah SWT, la yukallifullahu nafsan illa wus'aha.

Kata Kunci : hadits, rajam, hukum

\footnotetext{
${ }^{1}$ Dosen tidak tetap STAI Asy-Syukriyyah Tangerang
} 


\section{A. Pendahuluan}

Di dalam hukum pidana Islam (jinayah) sangat diutamakan terciptanya perlindungan terhadap setiap individu manusia. Ketentuan pidana Islam, khususnya mengenai hudud seperti potong tangan bagi pencuri, hukum rajam bagi pezina, serta qishash, masih mendapat sorotan tajam dari berbagai kalangan. Ekstrim kiri menganggap hukuman tersebut merupakan warisan primordial yang tidak hanya melanggar HAM, tapi juga amoral dan barbaric. Had yang sifatnya memang mutlak (absolut) padahal mempunyai unsur dan syarat ketat yang harus terpenuhi.

Pada tataran realita, jinayah seringkali terbentur dengan keadaan-keadaan yang sulit diselesaikan dengan berbagai pendekatan dan takwil. Hukum yang dipegang oleh suatu negara telah ditetapkan sebagai rujukan bagi semua warga yang bersangkutan, dan belum lagi penilaian dana komentar yang dilontarkan beberapa aktivis dan golongan sebagai bentuk resistensi terhadap pemberlakuan hukum rajam masih menjadi bahan diskusi yang perlu diperbincangkan. Makalah ini akan mengetengahkan wacana tersebut dengan pendekatan kritik hadis.

\section{B. Redaksi}

$$
\begin{aligned}
& \text { عن أبي هريرة أنه قال أتى رجل من المسلمين رسول الله صلى الله عليه وسلم وهو في المسجد فناداه } \\
& \text { فقال يا رسول الله إني زنيت فأعرض عنه فتنحى تلقاء وجهه فقال له يا رسول الله إني زنيت فأعرض عنه حتى }
\end{aligned}
$$

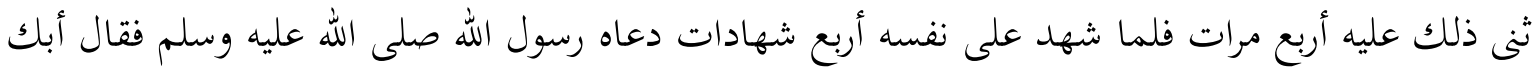

$$
\begin{aligned}
& \text { جنون قال لا قال فهل أحصنت قال نعم فقال رسول الله صلى الله عليه وسلم اذهبوا به فارجموه }
\end{aligned}
$$

${ }^{2}$ Sebagaimana dirincikan di dalam hadis lain, bahwa nama laki-laki Muslim disini adalah Ma'iz bin Malik al-Aslami. Di dalam kitab Syarah an-Nawawi, hadis ini disambung dengan peristiwa dirajamnya perempuan al-Ghamidiyah. Jadi bisa diasumsikan bahwa kedua hadis ini terjadi berurutan.

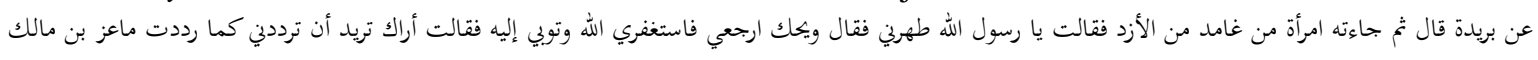

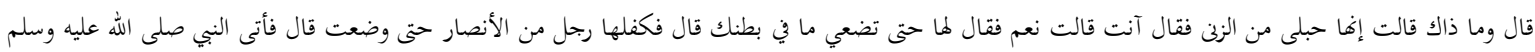

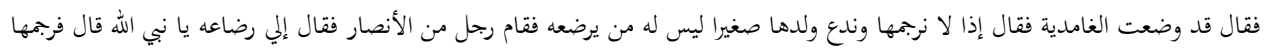

Muslim bin al-Hajjaj, Shahih Muslim, (Kairo: Dar Thayyibah, 1427 H), Kitab al-Hudud, Bab Man I'tarafa 'ala nafsihi biz Zina, No. Hadis: 1691. Lihat juga Yahya bin Syaraf an-Nawawi, Syarhu an-Nawawi ala Muslim, (Kairo: Dar al-Khair, $1416 \mathrm{H}$ ) 
Seorang laki-laki datang kepada Rasulullah SAW saat beliau berada di masjid. Laki-laki itu berkata, “wahai Rasulullah, aku telah berzina!”, namun beliau berpaling, lalu laki-laki itu pindah dan menghadap wajah beliau seraya berkata, "wahai Rasulullah, aku telah berzina!", beliau tetap memalingkan muka ke arah lain hingga hal itu terjadi berulang sampai empat kali, setelah laki-laki itu mengakui sampai empat kali bahwa dirinya telah berzina, Rasulullah SAW pun bersabda, “apakah kamu gila?” , orang itu menjawab, “tidak.” Beliau bertanya kepadanya lagi, “apakah kamu telah menikah?”, dia menjawab, "ya." Rasulullah SAW pun bersabda kepada para sahabat, "bawa orang ini, kemudian rajamlah dia."

$$
\begin{aligned}
& \text { قال الزهري أخبري عبيد الله أنه سمع أبا هريرة وزيد بن خالد قالا كنا عند النبي صلى الله عليه وسلم فقام }
\end{aligned}
$$

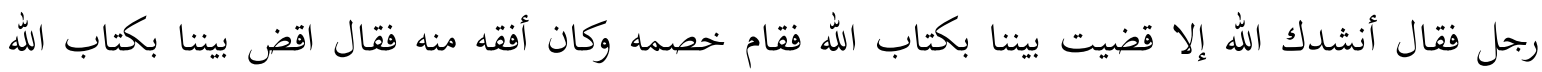

$$
\begin{aligned}
& \text { وأذن لي قال قل قال إن ابني كان عسيفا على هذا فزنى بامرأته فافتديت منه بمائة شاة وخادم تم سألت رجالا لئل } \\
& \text { من أهل العلم فأخبروين أن على ابني جلد مائة وتغريب عام وعلى امرأته الرجم فقال النبي صلى الله عليه وسلم } \\
& \text { والذي نفسي بيده لأقضين بينكما بكتاب الله جل ذكره المائة شاة والخادم رد عليك وعلى ابنك جلك إند مائة }
\end{aligned}
$$

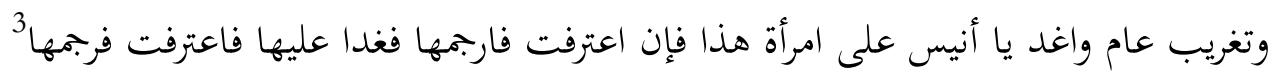

Dua orang laki-laki datang kepada Rasulullah SAW, kemudian salah seorang di antaranya berkata, "putuskanlah di antara kami dengan kitabullah dan izinkanlah aku untuk bicara.” Nabi berkata, "bicaralah” Ia melanjutkan, “anakku menjadi pekerja laki-laki ini, kemudian anakku berzina dengan istrinya, maka aku menebusnya dengan seratus ekor kambing dan satu pembantu, kemudian aku bertanya kepada beberapa ahli ilmu, mereka mengabariku bahwa anakku berkewajiban didera seratus kali dan diasingkan selama setahun, sedang perempuannya harus dirajam", maka Nabi SAW bersabda. "demi Dzat yang jiwaku berada di tangan-Nya, aku akan memutuskan di antara kalian dengan kitabullah yang agung sebutan-Nya. Kembalikan seratus ekor kambing dan pembantu itu, anakmu dicambuk seratus kali dan diasingkan setahun, dan pergila hai Unais ke istri

\footnotetext{
${ }^{3}$ Muhammad bin Isma'il al-Bukhari, Shahih Bukhari, (Kairo: Dar ar-Rayyan li at-Turats), Kitab al-Hudud, Bab al-I'tiraf biz Zina, No. Hadis: 6440
} 


\section{Jurnal Asy-Syukriyyah}

orang ini, jika dia mengakuinya, maka rajamlah dia." Unais pun pergi menemui istri orang tersebut dan ia mengakuinya, maka Unais merajamnya.

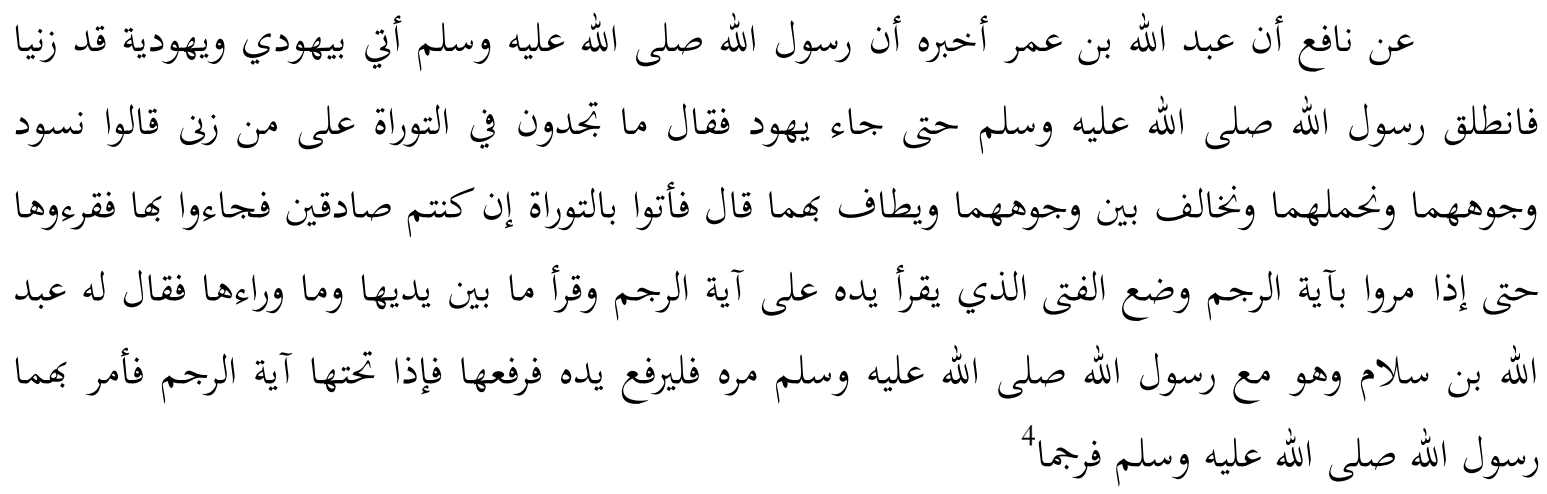

Dari Nafi' dari Abdullah bin Umar, bahwa seorang laki-laki dan seorang wanita dihadapkan kepada Rasulullah SAW karena keduanya tertuduh berbuat zina. Rasulullah SAW lantas pergi hingga menemui orang-orang Yahudi, beliau kemudian bertanya, "apa yang kalian ketahui dalam Taurat tentang hukuman bagi orang-orang yang telah berzina?”, mereka menjwab, "kami lumuri muka mereka dengan arang, kemudian kami naikkan kedua orang tersebut ke atas kendaraan dengan posisi berbelakang-belkangan lalu diarak keliling kota." Beliau SAW bersabda, "jika kalian benar, coba perlihatkan kitab Tauratmu!", lalu mereka bawa kitab Taurat dan mereka membacanya di hadapan beliau. Ketika bacaannya sampai kepada ayat rajam, pemuda yang membacanya meletakkan tangannya agar bisa menutupi ayat tersebut hingga lewat sampai ayat berikutnya. Tetapi Abdullah bin Salam, yang ketika itu mendampingi Rasulullah SAW berkata, "wahai Rasulullah, suruhlah dia mengangkat tangannya." Ketika pemuda itu mengangkat tangannya terdapat ayat rajam. Kemudian Rasulullah SAW memerintahkan keduanya dihukum rajam.

\footnotetext{
${ }^{4}$ Muslim bin al-Hajjaj, Shahih Muslim, (Kairo: Dar Thayyibah, 1427 H), Kitab al-Hudud, Bab Rajmi alYahud, No. Hadis: 3211
} 


\section{Kritik Sanad}

Kitab Shahih al-Bukhari dan Shahih Muslim dalam pandangan para ulama dianggap kitab yang paling sahih setelah al-Qur'an. Hadis-hadis yang termaktub di dalam keduanya pun dihukumi manqulatun 'ala al-ittishal. ${ }^{5}$ Sehingga pembahasan kualitas perawi-perawi hadis shahihain merupakan suatu bentuk pleonisme (tahshil al-hashil).

\section{Tafsir Kata}

1. Rajam: berasal dari kata رجم - يرجم - رجما ، فهو مرجوم ورجيم yang berarti melemparinya dengan batu. Adapun kalimat asy-syaithan ar-rajim berarti dielmpari dengan bintang-bintang dan laknat. Menurut ahli tafsir, kata marjum juga bermakna dijauhkan dan ditolak (مبعد مطرود). Islamic Penal Code of The Republic of Iran mendefinisikan hukum rajam sebagai berikut:

"Stoning is a form of capital punishment in which the convicted criminal is put to death by having stones thrown at them, generally by a crowd."7

2. Muhshan: dengan huruf shad difathahkan secara berasal dari kata al-ihshan, secara bahasa berarti benteng. Maknanya meluas menjadi kesucian (al-iffah), pernikahan (attajwiz) dan keislaman (al-islam). Dikatakan muhshan karena orang yang menikahkan lakilaki atau perempuan tersebut telah memberinya benteng terhadap perbuatan keji (fahisyah), yaitu akad nikah. Dikatakan mushin, dengan shad dikasrahkan dalam konteks si laki-laki atau perempuan melindungi dirinya sendiri, bukan dilindungi orang lain. ${ }^{8}$ Istilah lain dari muhsan adalah tsayyib.

Abdul Qodir 'Audah lebih jauh lagi menjelaskan, bahwa seseorang baru disebut muhshan apabila terpenuhi syarat-syarat berikut: 1) al-wath'u fi nikahin shahihin, yakni

\footnotetext{
5 'Ajjâj al-Khatib, Ushul al-Hadits, (Beirut: Dar al-Fikr, 1989), hal. 315; Muhammad Abdurrahman, Metode Kritik Hadis, (Bandung: PT Rosdakarya, 2013), hal. 234

${ }^{6}$ Ibnu Manzhur, Lisan al-'Arab, (Beirut: Dar al-Fikr), Bab Harf ar-Ra' hal. 117

${ }^{7}$ IHRDC (Iran Human Right Documentation Center), Islamic Penal Code of The Republic of Iran, January 2012

${ }^{8}$ Ibnu Hajar al-`Asqalani, Fathu al-Bari, (Kairo: Dar al-Khair, 1407 H), Juz-12, hal. 119
} 


\section{Jurnal Asy-Syukriyyah}

walaupun ia telah menikah namun belum melakukan hubungan badan maka belum termasuk kategori muhshan. 2) aqil baligh dan 3) wujud al-kamal fi ath-tharfayn, yakni kondisi aqil baligh harus terpenuhi oleh si laki-laki dan perempuan. Hadd rajam akan gugur jika salah satu dari keduanya gagal memenuhi syarat tersebut. ${ }^{9}$

\section{E. Pembahasan}

Sebagaimana hukum khamr yang diturunkan perlahan-lahan -menyesuaikan kadar keimanan kaum muslimin, hadd bagi pezina pun tidak langsung hukuman rajam. Pada masa awal, vonis bagi pezina perempuan yang sudah menikah -apabila telah tegak buktinya, adalah kurungan di dalam rumah (al-habsu), dan bagi laki-laki adalah celaan dan hinaan dari kaumnya $\left(a l-a d z a^{\prime}\right) .{ }^{10}$ Kemudian datang surat an-Nur ayat $2^{11}$ menghapus ketetapan tersebut, bahwa laki-laki dan perempuan pezina yang belum menikah hadd-nya adalah dicambuk seratus kali. ${ }^{12}$ Ayat rajam -yang tadinya bagian dari surat al-Ahzab, juga turun dengan redaksi:

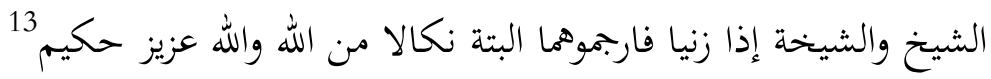

\footnotetext{
${ }^{9}$ Abdul Qodir 'Audah, at-Tasyri' al-Jina'i al-Islami, (Beirut: Dar al-Kutub al-'Araby), Juz-2, hal. 392

${ }^{10}$ Redaksinya:

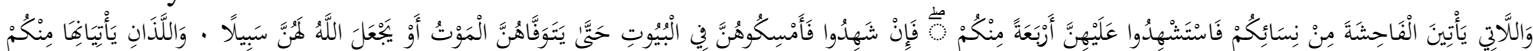

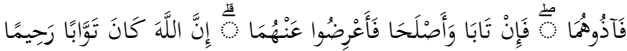

${ }^{11}$ Redaksinya:

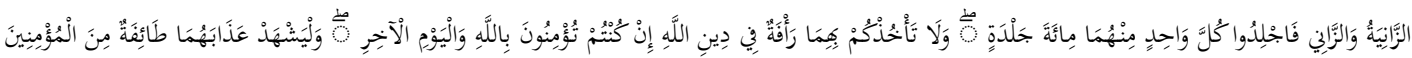

${ }^{12}$ Abdul Qodir 'Audah, at-Tasyri' al-Jina 'i al-Islami, (Beirut: Dar al-Kutub al-'Araby), Juz-2, hal. 376

${ }^{13}$ Sebagian ulama berpendapat bahwa pezina muhshan juga didera 100 kali sebelum dirajam, berangkat dari hadis Ubadah bin Shamit:

"Ikutilah semua ajaranku, ikutilah semua ajaranku. Sungguh, Allah telah menetapkan hukuman bagi mereka, perjaka dan perawan hukumannya adalah cambuk seratus kali dan diasingkan selama setahun, sedangkan laki-laki dan wanita yang sudah menikah hukumannya adalah dera seratus kali dan dirajam."

Muslim bin al-Hajjaj, Shahih Muslim, (Kairo: Dar Thayyibah, 1427 H), Kitab al-Hudud, Bab Hadd az-Zina, No. Hadis: 3199. Lihat juga Ibnu Hajar al-'Asqalani, Fathu al-Bari, (Kairo: Dar al-Khair, 1407 H), Juz-12, hal. $147-148$
} 
Rajam adalah salah satu contoh syari'at islam yang dihapus ayatnya namun tidak kontinuitas hukumnya (نسخ التلاوة دون الحكم). ${ }^{14}$ Hal ini senada dengan atsar dari Umar bin Khattab ra.: "Sesungguhnya aku khawatir, akan datang suatu zaman ketika manusia berkata: "Kita tidak mendapati rajam di dalam kitab Allah", sehingga mereka menjadi sesat dengan sebab meninggalkan satu kewajiban yang telah diturunkan oleh Allah. Ingatlah, sesungguhnya rajam adalah haq atas orang yang berzina dan dia telah menikah, jika; 1) bukti telah tegak (saksi), atau 2) ada kehamilan, atau 3) ada pengakuan. Ingatlah, Rasulullah SAW telah melakukan rajam, dan kita telah melakukan rajam setelah beliau."15

Dalam tataran aplikatif, hukum rajam sebenarnya telah cukup lama berlaku di banyak negara mayoritas Muslim. Misalnya Saudi Arabia, Sudan, Pakistan, Iran, beberapa negara bagian Malaysia (Trengganau, Kelantan), di beberapa wilayah Nigeria (Gombe, Jigawa, Kaduna, Kebbi, Bauchi, Yobe), dan bahkan di satu provinsi Indonesia, Aceh. Namun demikian, tata cara, syarat dan ketentuan rajam secara tertulis masih kurang memadai untuk menjelaskan penerapan hukum -yang padahal sangat membutuhkan ketelitian tersebut. ${ }^{16}$

Pada kasus Ma'iz bin Malik misalnya, ia harus mengulang empat kali pengakuannya sebelum mendapatkan atensi dari Nabi SAW. Di dalam riwayat lain disebutkan usaha konfirmasi Rasulullah selain mempertanyakan 'kewarasannya', yaitu

\footnotetext{
${ }^{14}$ Abu Muhammad Ibnu 'Athiyyah, al-Muharrar al-Wajiz fi Tafsir al-Qur'an al-'Aziz, (Beirut: Dar atTurats), hal. 131.

Disebutkan oleh sebagian ulama bahwa hikmah dihapusnya ayat rajam sebagai sindiran keras bagi orang Yahudi yang menegasikan hukum itu padahal secara terang-terangan tertulis di kitab mereka. Sedangkan umat Islam yang hanya hanya berbekal zhann dan keyakinan kuat, (yakni hadis Nabi yang tidak mencapai derajat mutawair al-Qur'an) tetap menerapkan hukum tersebut.

${ }^{15}$ Muhammad bin Isma'il al-Bukhari, Shahih Bukhari, (Kairo: Dar ar-Rayyan li at-Turats), Kitab al-Hudud, No. Hadis: 6829. Lihat juga Muslim bin al-Hajjaj, Shahih Muslim, (Kairo: Dar Thayyibah, 1427 H), Kitab alHudud, No. Hadis: 1691

${ }^{16}$ Sanaz Alasti, Comparative Study of Stoning Punishment in The Religions of Islam and Judaism, Justice Policy Journal, Vol. 4 No.1, 2007
} 


\section{Jurnal Asy-Syukriyyah}

ber-tabayyun kepada para sahabat tentang perihal Ma'iz apakah dia peminum $\mathrm{khamr}^{17}$, menegaskan lagi ke Ma'iz apakah yang dia lakukan betul-betul hubungan suami istri ${ }^{18}$, dan setelah itupun menasihatinya agar pulang dan bertaubat saja. ${ }^{19}$ Abu Daud mengabarkan dari jalur lain bahwa Ma'iz mengalami kesakitan yang luar biasa dan mencoba melarikan diri. Namun segera ditangkap sahabat untuk dilanjutkan proses hukuman rajam. Setelah Ma'iz meninggal dan diceritakan perihal tersebut kepada Rasulullah, beliau bersabda, تركتموه لعله أن يتوب فيتوب الله عليه, “Kenapa kalian tidak membiarkannya (lari)? Barangkali dia bertaubat dan Allah menerima taubatnya. "20

Perempuan hamil yang berasal dari Ghamid juga mendapat perlakuan serupa dari Nabi SAW ketika mengakui perkaranya. Beliau memerintahkan supaya ia melahirkan dulu bayi yang dikandungnya. Setelah melahirkan dan kembali datang menagih hukuman, Rasulullah 'berkilah' bahwa ia tidak akan dirajam karena tidak mungkin bayinya hidup tanpa dampingan seorang ibu. Akhirnya setelah seorang sahabat Anshar menyanggupi untuk menanggung bayi tersebut, barulah ia dirajam. Hal demikian -yakni menjauhi vonis pidana terhadap kaum muslimin memang Rasulullah sabdakan dan anjurkan pada hadis lain. $^{21}$

\footnotetext{
${ }^{17}$ Muslim bin al-Hajjaj, Shahih Muslim, (Kairo: Dar Thayyibah, 1427 H), Kitab al-Hudud, Bab Man I'tarafa 'ala nafsihi biz Zina, No. Hadis: 1695

${ }^{18}$ Redaksinya:

عن ابن عباس رضي الله عنهما قال ملا أتى ماعز بن مالك النبي صلى الله عليه وسلم قال له لعلك قبلت أو غمزت أو نظرت قال لا يا رسول الله قال أنكتها لا يكني قال فعند ذلك أمر برجمه

Dari Ibnu Abbas ra, ketika Ma'iz bin Malik menemui Nabi SAW, Nabi bertanya, "bisa jadi kamu hanya sekedar mencium, meraba atau memandang!", Ma'iz menjawab, "tidak ya Rasulullah!", beliau bertanya lagi, "apakah kamu benar-benar menyetubuhinya?", -Ibnu Abbas berkata, beliau tidak lagi menggunakan kiasan-, maka setalah mengakui itu Ma'iz pun dirajam.

Muhammad bin Isma'il al-Bukhari, Shahih Bukhari, (Kairo: Dar ar-Rayyan li at-Turats), Kitab al-Hudud, Bab Hal yaqu al-Imam: la'allaka lamasta au ghamazta, No. Hadis: 6824

${ }^{19}$ Muslim bin al-Hajjaj, Shahih Muslim, (Kairo: Dar Thayyibah, 1427 H), Kitab al-Hudud, Bab Man I'tarafa 'ala nafsihi biz Zina, No. Hadis: 1696

${ }^{20}$ Abu Daud Sulaiman bin al-Asy'ats, Sunan Abu Daud, (Beirut: Al-Maktabah al-‘Ashriyyah), hadis no. 3836

${ }^{21}$ Redaksinya:
} 
Kedua kasus tersebut, Ma'iz dan al-Ghamidiyah, merupakan penegakkan rajam yang berangkat dari pengakuan (al-i'tiraf) dan qarinat/bukti kehamilan (al-habla). Permasalahan menjadi rumit ketika bukti perzinaan berupa saksi mata, karena di masa Rasulullah pun tidak ditemukan contoh kasus demikian. Semua vonis rajam diberlakukan atas dasar pengakuan dan permintaan pelaku.

Dalam kitab at-Tasyri' al-Jina'i bab syahadah, diuraikan syarat-syarat persaksian yang apabila diejawantahkan pada peradaban manusia sekarang, nyaris tidak bisa terepenuhi. Perihal jumlah saksi, syari'at mewajibkan minimal empat orang laki-laki. Sesuai dengan firman Allah SWT surat an-Nisa ayat 105, surat an-Nur ayat 4 dan 13, dan hadis Nabi SAW:

$$
\text { رجلا أمهله حتى آتي بأربعة شهداء فقال رسول الله صلى الله عبادة قال لرسول الله صلى الله عليه وسلم أرأيت لو أني وجدت معل وسلم نعم امرأتي }
$$

Pernah seorang sahabat bernama Hilal bin Umayyah menuduh istrinya melakukan zina dengan Syarik bin Samha dan membawa persoalan tersebut ke hadapan Rasulullah. Lalu beliau bersabda البينة وإلا فحد في ظهرك (bawalah buktilempat orang saksi, atau kamu akan dihukum cambuk di punggungmu). Walaupun pada akhirnya istri Hilal melahirkan anak yang ciri-cirnya mirip Syarik -sebagaimana informasi Nabi SAW, namun hukum rajam tetap tidak ditegakkan karena bukti-buktinya tidak terpenuhi. ${ }^{23}$

Secara rinci, syarat-syarat persaksian pada jarimah hudud dibagi menjadi dua, syarat-syarat umum dan syarat-syarat khusus. Adapun syarat-syarat umum yaitu; 1) berakal, 2) baligh, 3) al-hifzhu, yakni seorang saksi harus mampu memahami dan mereka

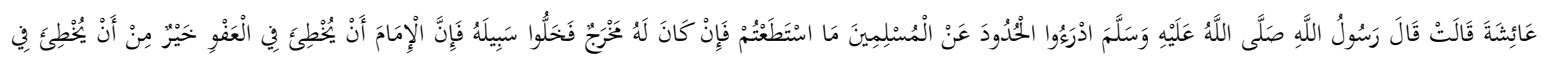
الُْعُعْبَّة

"Hindarkanlah hukuman-hukuman pidana dari kaum muslimin semampu kalian, jika kalian mendapatkan jalan keluar bagi seorang muslim, maka pilihlah jalan itu. Karena sesungguhnya seorang pemimpin yang salah dalam memberi maaf itu lebih baik dari pada pemimpin yang salah dalam menghukum "

Muhammad bin Isa at-Tirmidzi, Sunan at-Tirmidzi, Kitab al-Hudud, No. Hadis: 1344. Lihat juga al-Baihaqi, as-Sunan al-Kubra, Juz:8, hal. 238

${ }_{22}$ Muhammad bin Abdul Baqi az-Zarqani, Syarhu az-Zarqani 'ala Muwaththa' al-Imam Malik, (Beirut: Maktabah ats-Tsaqafah ad-Diniyah, $1424 \mathrm{H}$ )

${ }^{23}$ Muhammad bin Isma'il al-Bukhari, Shahih Bukhari, (Kairo: Dar ar-Rayyan li at-Turats), Kitab Tafsir alQur'an, No. Hadis: 4470 
ulang detail kejadian perkara, 4) mampu berbicara atau apabila ia bisu mampu menulis/memberi isyarat lain, 5) mampu melihat, 6) 'adalah, sebagaimana dijelaskan oleh kebanyakan fuqoha yakni yang menjauhi dosa kaba'ir dan terus menjaga diri dari dosa shaga'ir, 7) Islam. ${ }^{24}$

Selanjutnya syarat-syarat khusus dalam persaksian, yaitu; 1) minimal 4 laki-laki ${ }^{25}$, 2) al-ashalah, yakni menyaksikan perkara secara langsung ${ }^{26}$, artinya segala bentuk alat rekam seperti smartphone, audio recorder, camcorder, CCTV (Closed Circuit Television), hidden camera dan sejenisnya tidak dihitung sebagai saksi yang empat itu. Kesmuanya hanya menjadi alat bantu hakim dalam proses pertimbangan ${ }^{27}$, 3) menyegerakan dalam bersaksi. Syarat ini hanya diajukan oleh Abu Hanifah dengan dalih, perkara yang telah lama terjadi namun tiba-tiba diangkat oleh seorang saksi lebih menunjukkan motivasi tuduhan dan kebencian daripada keadilan, 4) Semua saksi berada di dalam satu majlis

\footnotetext{
${ }^{24}$ Terdapat banyak ikhtilaf ulama madzhab dalam menentukan 'kadar' setiap syarat tersebut. Misalnya kadar kebutaan seseorang yang bisa meraba dan mendengar, kadar ke-dhabit-an ingatannya dan kadar penyematan gelar 'adil. Namun dari segi nilai substantif semua pendapat mengerucut kepada tujuh poin di atas. Tentang syarat yang ketujuh -yaitu Islam, terdapat pengecualian apabila persaksian itu dari ahlu dzimmah kepada ahlu dzimmah yang lain, atau apabila dalam kondisi darurat, ketika tidak ada lagi orang muslim yang ada/bersedia menjadi saksi, maka dalam dua konteks tersebut sebagian ulama membolehkan persaksian dari non-muslim.
}

Abdul Qodir 'Audah, at-Tasyri' al-Jina'i al-Islami, (Beirut: Dar al-Kutub al-'Araby), Juz-2, hal. 399-405

${ }^{25}$ Jumhur ulama sepakat bahwa persaksian hudud-keempat-empatnya, hanya dari laki-laki. Namun terdapat suatu riwayat dari 'Atha dan Hammad bahwa keduanya menerima persaksian perempuan apabila memang

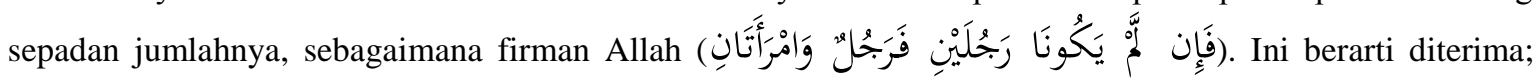
kesakisan 3 laki-laki dan 2 perempuan, kesaksian 2 laki-laki dan 4 perempuan, atau kesaksian 1 laki-laki dan 6 orang perempuan. Adapun persaksian suami terhadap istrinya (yang berzina), tidak diperkenankan oleh Malik, as-Syafi'i dan Ahmad. Sedangkan Abu Hanifah membolehkan hal tersebut karena tudahan suami itu tidak memberikan manfaat apapun kepadanya, dan justru malah membeberkan aibnya.

${ }^{26}$ Hanya golongan $d z$ ahiriyyah yang membolehkan persaksian secara tidak langsung. Misalnya dari 4 saksi, hanya 2 orang yang melihatnya tanpa tedeng aling-aling, dan 2 orang lagi bersaksi bahwa persaksian kedua sahabat mereka adalah benar. Selama mereka terjamin 'adalah-ny yang demikian tidak masalah. Mereka berdalih bahwa Allah SWT memerintahkan kaum muslimin untuk menerima persaksian orang-orang adil.

Ibnu Hazm al-Andalusi, al-Muhalla, Juz-9, hal. 438

${ }^{27}$ Dikutip dari kesimpulan paper Misbahun Nasrullah, bahwa kekuatan barang bukti elektronik dalam hukum pidana Islam hanya dapat digunakan untuk meyakinkan hakim -dengan tetap memperhatikan qarinat lain, dan hakim berhak memutuskan perkara dengan keyakinannya, berpijak dari rekaman media elektronik sebagai alat bantu di persidangan.

Mibahun Nasrullah, Analisis Hukum Pidana Islam Terhadap Kekuatan Barang Rekaman Elektronik dalam Putusan Tinda Pidana Pencurian, Skripsi, (Surabaya: UIN Sunan Ampel, 2018), hal. 72 
persidangan, 5) Hakim memastikan lagi detail kejadian perkara, yakni bila dalam proses hearing, antara saksi satu berbeda dengan saksi yang dalam menceritkan perihal tempat, waktu, keadaan atau apapun itu yang berhubungan dengan peristiwa, maka bagi mereka hadd qadzf. Mengkonfirmasi kiranya semua saksi telah memenuhi kriteria umum dan khusus dalam persaksian menjadi tugas tambahan juga bagi hakim. ${ }^{28}$

Maka dapat disimpulkan bahwa hukuman rajam tidak akan ditegakkan apabila satu saja dari semua syarat di atas belum terpenuhi. Jika 1 dari 4 saksi yang maju ke persidangan ternyata tidak memenuhi syarat 'adalah, maka bagi mereka hukum cambuk (qadzf). Jika salah seorang di antara mereka berbeda menceritakan alur peristiwa, maka bagi mereka hukum cambuk. Demikian seterusnya sampai kesemua syarat itu terwujud barulah hadd rajam berlaku.

Andai semua syarat itu terkumpul pun, hukum rajam masih bisa dibatalkan apabila; 1) terdapat hubungan kekerabatan (al-qarabah) antara syahid dan masyhud, misal bapak terhadap anaknya, atau anak terhadap bapaknya, 2) terdapat riwayat permusuhan (al'adawah) antara syahid dan masyhud, namun sebatas urusan duniawi seperti harta, warisan, perdagangan dan lain-lain. Jika permusuhan itu di dalam ranah agama, membencinya karena sifat fasiq-nya, sifat kufur-nya, maka yang demikian tidak mengapa, 3) terdapat motivasi tuduhan, yakni kemungkinan bersaksi hanya untuk mencelakakan masyhud, misal kesaksian orang yang berhutang terhadap orang yang menghutanginya, kesaksian pembantu terhadap majikannya, atau kesaksiannya dibeli (risywah), dan berbagai posibilitas lainnya. ${ }^{29}$

Tentang siapa yang merajam -sebagaimana disebutkan pada redaksi hadis kedua, Rasulullah bahkan tidak hadir dan mewakilkan penegakkan hukum itu kepada Unais, jadi

\footnotetext{
${ }^{28}$ Tentang keputusan hakim, ia tidak diperkenankan menjatuhkan vonis kepada seseorang tanpa 4 saksi, walaupun pada kenyataannya ia sendiri menyaksikan peristiwa tersebut. Berangkat dari atsar Abu Bakar ra.:

لو رأيت رجلاً على حد لم أحده حتى تقوم البينة عندى

Abdul Qodir 'Audah, at-Tasyri' al-Jina'i al-Islami, (Beirut: Dar al-Kutub al-'Araby), Juz-2, hal. 407-430. Lihat juga Sayyid Sabiq, Fiqh Sunnah, (Kairo: al-I'lam al-'Araby), Juz-2, hal. 268

${ }^{29}$ Abdul Qodir 'Audah, at-Tasyri' al-Jina 'i al-Islami, (Beirut: Dar al-Kutub al-'Araby), Juz-2, hal. 410-412
} 


\section{Jurnal Asy-Syukriyyah}

'merajam' tidak menjadi wewenang eksklusif seorang imam/amir suatu wilayah. ${ }^{30}$ Namun karena hadd itu berkaitan dengan haq Allah dan kemaslahatan bersama, maka izin dari pemimpin struktural tertinggi -apapun bentuk sistem pemerintahnnya, harus tetap ada. Rasulullah SAW bersabda:

$$
\text { أربعة إلى السلطان : الصلاة ، والزكاة ، والحدود ، والقصاص } 31
$$

"Empat perkara yang harus dikembalikan kepada penguasa: sholat, zakat, hudud dan qishash."

Tidak ditemukan perbedaan pendapat tentang publikasi proses hudud, karena nash

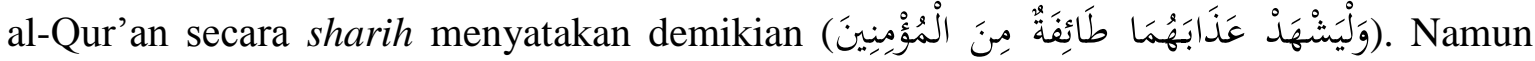
perihal berapa banyak massa yang harus ada dalam prosesi rajam, belum ditemukan bilangan yang pasti. Sebagian mengatakan bahwa tha'ifah adalah cukup satu orang ekeskutor dan satu orang saksi, sebagian lain mengatakan dua orang saksi, sebagian empat dan sebagian sepuluh.

Mengutip dari jurnal Sanaz Alasti, bahwa dari sekian negara Muslim yang menerapkan hukum rajam -terlepas dari kecaman dunia internasional berkaitan dengan human rights, hanya Iran yang memiliki rincian tertulis tentang bagaimana rajam itu dilakukan. Pada IHRDC (Iran Human Right Documentation Center), Section 4-The Procedure of Execution of the Hadd Punishment, article 101 tertulis:

"It is approppriate that the judge informs people of the time of execution of hadd punishment and it is necessary that not less than three pious people attend the execution

\footnotetext{
30 Islamic Penal Code of The Republic of Iran menyebutkan:

"If the zina of a mohsan is proved by his/her confession, the first stone shall be cast by the shari' $a$ judge followed by others, and if the zina is proved by testimony of witnesses, first of the witness shall cast the stones followed by the judge and then others." Hal ini menarik disebutkan sebagai bahan perbandingan.

Ibnu Hajar al-'Asqalani, Fathu al-Bari, (Kairo: Dar al-Khair, 1407 H), Juz-12, hal. 141. Lihat juga Syarah an-Nawawi, No. Hadis 1698

${ }^{31}$ Hadis ini diniali gharib oleh az-Zaila'i namun memiliki beberapa syahid. Lihat Jamaluddin az-Zaila'i, Nashbu ar-Riwayah fi Takhriji Ahaditsi al-Hidayah, (Kairo: Dar al-Hadits, 1415 H), Juz-4, hal. 120
} 
of hadd punishment." Selain menganjurkan seluruh masyarakat hadir, Republik Iran juga menambah parameter 'tiga orang soleh dan alim', atau hadd tidak ditegakkan. ${ }^{32}$

Berdasarkan kasus Ma'iz bin Malik, para ulama berpendapat bahwa orang yang dirajam tidak mesti dikubur, diikat atau dikekang, melainkan hanya dibiarkan berdiri kemudian dilempari batu. ${ }^{33}$ Apabila ia dirajam karena pengakuan (al-i'tiraf), dan lari di tengah proses hadd, maka yang rajih adalah membiarkannya -sebagaimana redaksi hadis Nabi SAW. Namun jika ia dirajam karena persaksian orang lain atasnya, hukum rajam tetap dilangsungkan walaupun si marjum kesakitan dan mencoba lari. Pada konteks demikian barulah wasilah dikubur, ikatan dan kekangan digunakan. ${ }^{34}$ Batas kedalaman hufrah (penguburan) bagi laki-laki sampai pinggang dan bagi perempuan sampai bagian dada diutarakan oleh Abu Hanifah, dengan alasan terkoyaknya pakaian pada saat proses rajam, sehingga yang demikian lebih menutup aurat si perempuan.

Perihal posisi merajam, Abdul Qodir Audah menyebutkan dua contoh, namun tidak mencantumkan hadis atau atsar dari contoh tersebut, yaitu dengan melemparinya dari segala sisi (melingkar), atau jika dikhawatirkan massa yang hadir akan terlempar batu satu sama lain, opsi keduanya adalah dari sisi depan saja dengan bentuk shaf shalat. ${ }^{35}$ Tempatnya lebih diutamakan di lapangan luas (al-baqi') yang jauh dari rumah penduduk sebagaimana redaksi dari Abu Sa'id bahwa Ma'iz dirajam di al-baqi' Gharqad. Waktu penangguhan rajam hanya ada bagi perempuan hamil, seperti termaktub pada hadis al-

\footnotetext{
${ }^{32}$ Sanaz Alasti, Comparative Study of Stoning Punishment in The Religions of Islam and Judaism, Justice Policy Journal, Vol. 4 No.1, 2007, hal. 24. Lihat juga Abdul Qodir 'Audah, at-Tasyri' al-Jina'i al-Islami, (Beirut: Dar al-Kutub al-'Araby), Juz-2, hal. 445, IHRDC (Iran Human Right Documentation Center), Islamic Penal Code of The Republic of Iran, January 2012, hal. 19

${ }^{33}$ Redaksinya dari Abu Sa'id:
} فانطلقنا به إلى بقيع الغرقد قال فما أوثثناه ولا حفرنا له قال فرميناه بالعظم Yahya bin Syaraf an-Nawawi, Syarhu an-Nawawi 'ala Muslim, (Kairo: Dar al-Khair, 1416 H), No. Hadis: 1694

34 Abu Hanifah menyendiri dalam pendapat bahwa perempuan harus dikubur dalam setiap konteks rajam baik itu pengakuan atau persaksian. Abdul Qodir 'Audah, at-Tasyri' al-Jina'i al-Islami, (Beirut: Dar alKutub al-'Araby), Juz-2, hal. 446

${ }^{35}$ Abdul Qodir 'Audah, at-Tasyri' al-Jina'i al-Islami, (Beirut: Dar al-Kutub al-'Araby), Juz-2, hal. 446 


\section{Jurnal Asy-Syukriyyah}

Ghamidiyah. Selain konteks kehamilan, tidak ada alasan sakit ${ }^{36}$, musim hujan/musim dingin, siang/malam atau hari-hari tertentu yang bisa mengulur prosesi hukum rajam.

Tentang ukuran dan jumlah batu yang digunakan juga tidak ditemukan hadis dan atsar yang mensifatinya secara definit. Hanya saja, menurut Abdul Qodir, karena memang konotasi 'dilempari' itu berkali-kali, dianjurkan agar batu yang digunakan tidak terlalu besar sehingga tervonis tidak seketika mati dengan one hit blow.

Dari segi kaffarat (redemption), rajam benar menjadi salah satu pintu diterimanya taubat seorang muhshan yang berzina. Akan tetapi menimbang redaksi hadis Ma'iz dari Abu Daud, rajam bukanlah satu-satunya pintu. ${ }^{37}$ Tentunya Allah SWT lebih tahu siapa yang paling mulia antara hamba yang bertaubat dengan rajam, atau hamba lain yang memilih melangsungkan hidupnya, dan terus beristiqomah dalam kebaikan. Wallahua'lam bi muradihi.

\section{F. Kesimpulan}

Hukum rajam dipandang oleh pembela HAM dan orientalis sebagai tip of the icebergnya pemahaman Islam yang fundamentalis dan primordialis. Namun setelah seseorang keluar dari 'penjara diksi' kata rajam, ia akan menemukan bahwa nyaris mustahil hukum ini diterapkan. Dari pembahasan sebelumnya bahkan tersirat, bahwa Nabi SAW sendiri sebenarnya ingin sekali menutup pintu hadd rajam rapat-rapat. Apabila tegaknya jinayat adalah bagian dari cita-cita kaum muslimin, barangkali langkah pertama yang harus ditempuh adalah menjelaskan dan 'memasarkan' hukum-hukum tersebut semenarik mungkin, hingga ia tak lagi jadi sebuah momok yang menakutkan. Dan jika jinayat tidak kunjung menjadi sebuah keniscayaan, khususnya di Indonesia, maka kita berpegang dengan firman Allah SWT, la yukallifullahu nafsan illa wus'aha.

\footnotetext{
36 Apabila terdakwa sakit dan baginya hadd deraan, maka hukumnya ditangguhkan sampai ia sembuh, khawatir deraan itu akan membunuhnya. Namun dalam kasus rajam, karena memang tujuannya adalah mengakhiri hidupnya (muhlik), maka alasan sakit tidak dapat diterima. Abdul Qodir 'Audah, at-Tasyri' alJina 'i al-Islami, (Beirut: Dar al-Kutub al-'Araby), Juz-2, hal. 447

${ }^{37}$ Muhammad Syamsul Haqq, 'Aun al-Ma'bud 'ala Syarhi Sunan Abi Daud, (Kairo: Dar al-Fikr, 1415 H), No. Hadis. 4419
} 
Plagiarism Detector v. 1092 - Originality Report:

Analyzed document 14:07/2019 054011

"Hadis Rajam- Revised.docx"

Licensed to

Relation chart

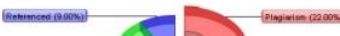

(0manes

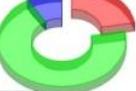

Distribution grapi

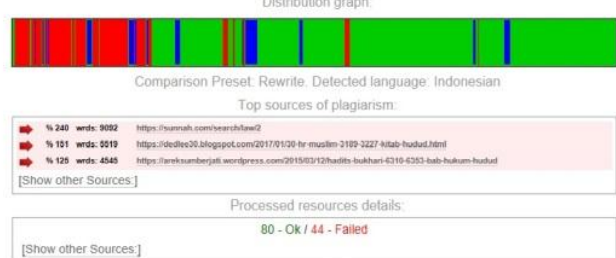

Hampir semua deteksi plagiasi dari redaksi hadis dan terjemahnya yang tidak bisa dihindari. Berikut rinciannya di bawah:

\begin{tabular}{|c|c|}
\hline \multicolumn{2}{|l|}{$\begin{array}{l}\text { Hadis-Hadis Rajam dalam Shahihain Oleh: Munammad Asgar Muzakki } \\
\text { NIM } 31181200000009\end{array}$} \\
\hline (10) Plagiarism detected: $3,49 \% \mathrm{nttps}: / / \mathrm{sunn}$ ah.com/search/law/2 +24 more resources! & id 1 \\
\hline \multicolumn{2}{|c|}{ 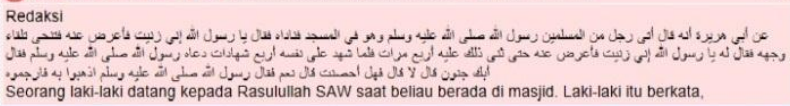 } \\
\hline m Quotes detected: $\mathbf{0 , 1 9 \%}$ in quotes: & id 2 \\
\hline \multicolumn{2}{|l|}{ "wahai Rasulullah, aku telah berzinal" } \\
\hline (120) Plagiarism detected: $0,49 \%$ https://sunnah com/search/law/2 +24 more resources! & id 3 \\
\hline \multicolumn{2}{|l|}{, namun beliau berpaling, lalu lakl-laki itu pindah dan menghadap wajah beliau seraya berkata, } \\
\hline m Quotes detected: $\mathbf{0 , 1 9 \%}$ in quotes: & id. 4 \\
\hline \multicolumn{2}{|l|}{ "wahai Rasulullah, aku telah berzinal" } \\
\hline (12) Plagiarism detected: $1,12 \%$ https://sunnah.com/search/law/2 +24 more resources! & id 5 \\
\hline \multicolumn{2}{|c|}{$\begin{array}{l}\text { beliau tetap memalingkan muka ke arah lain hingga hal itu terjadi berulang sampai empat kali, setelah laki-laki } \\
\text { itu mengakui sampai empat kall bahwa dirinya telah berzina, Rasulullah SAW pun bersabda, }\end{array}$} \\
\hline \% Quotes detected: $0,11 \%$ in quotes: & id 6 \\
\hline \multicolumn{2}{|l|}{ "apakah kamu gila?" } \\
\hline $\begin{array}{l}\text { (120) Plagiarism detected: } 0,11 \% \text { hitps: } / / \text { sunnah com/search/law/2 }+24 \text { more resources! } \\
\text { orang itu menjawab, }\end{array}$ & id 7 \\
\hline p. Quotes detected: $0,04 \%$ in quotes: & id: 8 \\
\hline \multicolumn{2}{|l|}{ "tidak." } \\
\hline (202) Plagiarism detected: $0,15 \%$ hittps://sunnah.com/search/law/2 + 24 more resources! & id: 9 \\
\hline \multicolumn{2}{|l|}{ Beliau bertanya kepadanya lagi, } \\
\hline P. Quotes detected: $0,15 \%$ in quotes: & id. 10 \\
\hline \multicolumn{2}{|l|}{ "apakah kamu telah menikah?" } \\
\hline $\begin{array}{l}\text { (22) Plagiarism detected: } 0,07 \% \text { hitps: } / / \text { sunnah.com/search/law } / 2+24 \text { more resources! } \\
\text { dia menjawab. }\end{array}$ & id. $\mathbf{1 1}$ \\
\hline W Quotes detected: $0,04 \%$ in quotes: & id 12 \\
\hline \multicolumn{2}{|l|}{ "ya." } \\
\hline (20) Plagiarism detected: $0,26 \%$ https: //sunnah.com/search/law/2 +24 more resources! & id. 13 \\
\hline \multicolumn{2}{|l|}{ Rasulullah SAW pun bersabda kepada para sahabat, } \\
\hline p. Quotes detected. $0,19 \%$ in quotes: & id 14 \\
\hline "bawa orang ini, kemudian rajamlah & \\
\hline Plagiarism detected: $4.84 \%$ & \\
\hline
\end{tabular}




\section{Daftar Pustaka}

Abdul Qodir 'Audah, at-Tasyri’ al-Jina'i al-Islami, (Beirut: Dar al-Kutub al-'Araby),

Abu Muhammad Ibnu 'Athiyyah, al-Muharrar al-Wajiz fi Tafsir al-Qur'an al-'Aziz, (Beirut: Dar at-Turats),

Abu Daud Sulaiman bin al-Asy'ats, Sunan Abu Daud, (Beirut: Al-Maktabah al'Ashriyyah),

‘Ajjâj al-Khatib, Ushul al-Hadits, (Beirut: Dar al-Fikr, 1989),

HRDC (Iran Human Right Documentation Center), Islamic Penal Code of The Republic of Iran, January 2012

Ibnu Hajar al-'Asqalani, Fathu al-Bari, (Kairo: Dar al-Khair, 1407 H),

Ibnu Manzhur, Lisan al-'Arab, (Beirut: Dar al-Fikr),

Jamaluddin az-Zaila'i, Nashbu ar-Riwayah fi Takhriji Ahaditsi al-Hidayah, (Kairo: Dar alHadits, $1415 \mathrm{H}$ ),

Muhammad Abdurrahman, Metode Kritik Hadis, (Bandung: PT Rosdakarya, 2013),

Muslim bin al-Hajjaj, Shahih Muslim, (Kairo: Dar Thayyibah, 1427 H),

Muhammad bin Isma'il al-Bukhari, Shahih Bukhari, (Kairo: Dar ar-Rayyan li at-Turats),

Muhammad bin Isa at-Tirmidzi, Sunan at-Tirmidzi, Kitab al-Hudud, No. Hadis: 1344. Lihat juga al-Baihaqi, as-Sunan al-Kubra,

Muhammad bin Abdul Baqi az-Zarqani, Syarhu az-Zarqani 'ala Muwaththa' al-Imam Malik, (Beirut: Maktabah ats-Tsaqafah ad-Diniyah, $1424 \mathrm{H}$ )

Mibahun Nasrullah, Analisis Hukum Pidana Islam Terhadap Kekuatan Barang Rekaman Elektronik dalam Putusan Tinda Pidana Pencurian, Skripsi, (Surabaya: UIN Sunan Ampel, 2018),

Muhammad Syamsul Haqq, 'Aun al-Ma'bud 'ala Syarhi Sunan Abi Daud, (Kairo: Dar alFikr, $1415 \mathrm{H}$ ),

Sanaz Alasti, Comparative Study of Stoning Punishment in The Religions of Islam and Judaism, Justice Policy Journal, Vol. 4 No.1, 2007

Sayyid Sabiq, Fiqh Sunnah, (Kairo: al-I'lam al-'Araby),

Yahya bin Syaraf an-Nawawi, Syarhu an-Nawawi 'ala Muslim, (Kairo: Dar al-Khair, 1416 $\mathrm{H})$ 